\title{
The Influence of the Structure of Several New ortho-Hydroxy-Ketone Derived bis-Schiff Bases on Their Antibacterial and Anti-Inflammatory Activity
}

\begin{abstract}
GLADIOLA TANTARU ${ }^{1}$, MIHAi APOSTU ${ }^{1}$, CRISTINA MIHAELA GHICIUC ${ }^{2}$, ANTONIA POIATA ${ }^{2}$, ALINA STEFANACHE ${ }^{1}$, MADALINA VIERIU ${ }^{1}$

${ }^{1}$ Grigore T. Popa University of Medicine and Pharmacy, Faculty of Pharmacy, 16 Universitatii Str., 700115, Iasi, Romania

${ }^{2}$ Grigore T. Popa University of Medicine and Pharmacy, Faculty of Medicine, $16^{\text {th }}$ Universitatii Street, 700115, Iasi, Romania

The article presents some bis-Schiff bases - halogenated derivatives of ortho-hydroxy-ketones with great potential for antimicrobial and antiinflammatory activity. The antimicrobial activities of the Schiff bases were tested in comparison with Chloramphenicol, Nystatin, and Ampicillin upon the following strains: Staphylococcus aureus (ATCC 25923), Sarcina lutea (ATCC 9341), Escherichia coli (ATCC 25922), Pseudomonas aeruginosa (ATCC 27853), Candida albicans (ATCC 1023), Candida glabrata, two Staphylococcus aureus strains, and several clinical isolates (Proteus mirabilis, Pseudomonas aeruginosa, Escherichia coli, Klebsiella pneumoniae). Those compounds were found to be active against Gram-positive or Gram-negative bacteria, and had an anti-inflammatory effect comparable to that of Indomethacin.
\end{abstract}

Keywords: Bis-Schiff base, anti-inflammatory effect, antimicrobial effect, experimental pharmacology

Compounds with azomethine groups $(-\mathrm{C}=\mathrm{N}-)$ in their structures are known as Schiff bases. They are usually synthesized from the condensation of primary amines with compounds with active carbonyl groups [1]. The biological activities of the Schiff bases have been attracting the attention of researchers of Organic Chemistry and Medicine. Nowadays, Schiff bases are well known for their importance as anticancer [2], antimicrobial [3, 4], anti-inflammatory [5-8], antiviral [9], analgesic [10], and anti-oxidizing [11-15] agents but a systematic study regarding their structureactivity relationship has not been reported so far. That was the reason why, we have started a complex study by designing Schiff bases that contained different halogens in different positions and vicinities, with the aim of clarifying the role of these groups in their antimicrobial and anti-inflammatory activity. A Schiff base without any substituent has been used for comparison.

The acute or chronic inflammatory process has a complex mechanism. The inflammation is determined by chemical mediators, which present various structures. Several studies proved that bis-Schiff bases reduced the synthesis of some chemical mediators of acute inflammation such as leukotrienes which are implicated in the formation of free radicals [9, 12-18].

Based on the above-mentioned applications of Schiff bases, this study presents the synthesis, physico-chemical characterization, antimicrobial, and anti-inflammatory effects of several new bis-Schiff bases.

\section{Experimental part}

For the study of the antimicrobial activity, the following strains were used: Staphylococcus aureus (ATCC 25923), Sarcina lutea (ATCC 9341), Escherichia coli (ATCC 25922), Pseudomonas aeruginosa (ATCC 27853), Candida albicans (ATCC 1023), Candida glabrata, two Staphylococcus aureus strains, and several clinical isolates (Proteus mirabilis, Pseudomonas aeruginosa, Escherichia coli, Klebsiella pneumoniae). Chloramphenicol, Ampicillin, Nystatin purchased from Himedia-Spain were used as reference substances.

The original bis-Schiff bases (fig. 1) were 2,2'-etilen-bis(4-chloro-2-(1-imino-propil))-phenol (BSB-Cl), 2,2'etilen-bis(4,6-dichloro-2-(1-imino-propil))-phenol (BSB-2Cl), 2,2'-methylen-bis(4,6-dibromo-2-(1-imino-ethyl))phenol (BSB-2Br), and 2,2'-methylen-bis(4,6-diiodo-2-(1-imino-ethyl))-phenol (BSB-2I). The preparation of the bisSchiff bases was done according to the following method: the corresponding ortho-hydroxy-ketone was dissolved in methanol (5:25), then it was mixed with $30 \%$ aqueous formaldehyde solution and $25 \%$ aqueous ammonia solution in a

\footnotetext{
*email: cristina.ghiciuc@umfiasi.ro
} 
30:5:5 ratio, and then the mixture was left to rest for 48 hours at room temperature. The precipitates were filtered, washed with methanol, and then recrystallized. Solid yellow substances were obtained with an approximately $50 \%$ $65 \%$ yield $[19,20]$.<smiles>CCC(=NC/N=C(\CC)c1cc(Cl)ccc1O)c1cc(Cl)ccc1O</smiles>

BSB-Cl<smiles>CC(=NCN=C(C)c1cc(Br)cc(Br)c1O)c1cc(Br)cc(Br)c1O</smiles><smiles>CCC(=NC)c1cc(Cl)cc(Cl)c1O</smiles>

$B S B-2 C l$<smiles>CCC(=N)c1cc(Cl)cc(Cl)c1O</smiles>

Fig. 1. The structures of the new ligands<smiles>CC(=NCN=C(C)c1cc(I)cc(I)c1O)c1cc(I)cc(I)c1O</smiles>

$B S B-2 I$

Chloramphenicol, Ampicillin, and Nystatin were used as reference substances against Gram-positive and Gramnegative bacteria: Staphylococcus aureus (ATCC 25923), Sarcina lutea (ATCC 9341), Escherichia coli (ATCC 25922), Pseudomonas aeruginosa (ATCC27853), Candida albicans (ATCC 1023), two strains of Staphylococcus aureus, Candida glabrata, and several clinical isolates (Proteus mirabilis, Pseudomonas aeruginosa, Escherichia coli, Klebsiella pneumoniae).

The protocol of the experimental study had been approved by the Institutional Ethical Committee (23983/2014). The animals used were male CD1 Wistar rats weighing 180-220 g, purchased from Cantacuzino Institute (Bucharest, Romania). Animal care and handling was done in accordance with the international guidelines for laboratory animal use and care as found in Directive 2010/63/EU. The animals were housed in polypropylene cages under controlled environmental conditions of temperature $\left(22 \pm 2^{\circ} \mathrm{C}\right)$, humidity $(50-70 \%)$, light (12 hours light/dark cycle), on $\mathrm{ad}$ libitum access to food and water, for 7 days before testing.

\section{Antimicrobial activity}

They were evaluated for antimicrobial activity against Gram-positive and Gram-negative bacteria. The qualitative antimicrobial assay of the compounds was performed using the agar diffusion method according to standard accepted disk sensitivity criteria of National Committee for Clinical Laboratory Standards.

The agar disk diffusion procedure is a method approved by the National Committee for Clinical Laboratory Standards (NCCLS) and was one of the first methods for evaluating the in vitro efficacy of antimicrobial agents. The microbiological assay is one in which the antimicrobial agent placed in a reservoir (paper disk or cylinder), diffuses directly against seeded bacteria.

A standard suspension of each reference strain was prepared from fresh overnight cultures, and it was mixed with $15 \mathrm{~mL}$ of molten nutrient agar in a sterile Petri plate resulting in a final concentration of about $10^{6} \mathrm{cells} / \mathrm{mL}$. When the plates were solid metal cylinders $(6 \mathrm{~mm}$ inner diameter) were placed on the surface of the medium and $0.2 \mathrm{~mL}$ samples were transferred into each well. Commercially available standard disks of Ampicillin $(10 \mu \mathrm{g})$, Chloramphenicol $(30 \mu \mathrm{g})$, and Nystatin $(100 \mu \mathrm{g})$ were used for comparison. Each microorganism was tested in triplicate and the zones of inhibition around the wells were measured after incubation at $37^{\circ} \mathrm{C}$ for 24 hours. The values of diameter of the inhibition zones are expressed as mean \pm SD.

\section{Anti-inflammatory activity}

Experimental design: animals were randomly distributed into six groups $(n=6)$; negative control group received $0.5 \mathrm{~mL}$ aqueous solution of sodium carboxymethylcellulose, positive control group received Indomethacin sodium salt $(10 \mathrm{mg} / \mathrm{kg})$, and test groups received BSB-2Br $(10 \mathrm{mg} / \mathrm{kg})$, BSB-2I $(10 \mathrm{mg} / \mathrm{kg})$, BSB-Cl $(10 \mathrm{mg} / \mathrm{kg})$, respectively $\mathrm{BSB}-2 \mathrm{Cl}(10 \mathrm{mg} / \mathrm{kg})$. All the substances were administered orally as a suspension in $0.5 \%$ sodium carboxymethylcellulose. 


\section{Carrageenan induced paw edema method}

It is one of the most commonly used methods for the screening of the anti-inflammatory effects of drugs. The substances for the controls and test groups were administered one hour before the induction of acute inflammation in the sub-plantar region of the right hind paw with $0.2 \mathrm{~mL}$ of freshly prepared $2 \%$ suspension of carrageenan in saline $(0.9 \%)$ subcutaneously. The paw was marked in order to immerge it always at the same level in the measurement chamber and the measurement was performed always in double blind, by the same operator. The paw volumes were measured before and at 1,2, 4, 6, 8, and 24 hours after the carrageenan injection using the volume displacement method resorting to a digital Plethysmometer (model LE7500, Panlab, Barcelona, Spain). The anti-inflammatory activity was evaluated based on the variation of the volume of inflammation paw edema. The percentage (\%) increase in the paw volume at each time interval was calculated using the formula: $\%$ Increase of the paw volume $=($ Paw volume at time $\mathrm{T}$ - Initial volume) / Initial volume $\times 100$ [21].

\section{Statistical analysis}

All the values are expressed as mean \pm standard error of mean (SEM). Statistical significance was calculated by one-way ANOVA followed by post hoc Tukey's multiple comparison test. Values of $p<0.05$ were considered statistically significant.

\section{Results and discussions}

Antimicrobial activity

The antimicrobial activity was estimated by measuring the diameter of the area inhibited by the tested new Schiff bases. For testing, we used the cylinder technique that was more sensitive than paper disc techniques. Table 1 includes the results of the diffusion tests on Mueller-Hinton agar from three different concentrations of tested compounds. Those results were attributed to the structure of the tested compounds that seemed to be the main factor influencing the antibacterial activity. That property was directly correlated to the ability of a compound to diffuse through biological membranes to reach its site of action.

Table 1

IN VITRO ANTIMICROBIAL ACTIVITY OF THE COMPOUNDS AGAINST GRAM-POSITIVE STRAINS AND FUNGIS

\begin{tabular}{|c|c|c|c|c|c|c|c|}
\hline \multirow{2}{*}{\multicolumn{2}{|c|}{$\begin{array}{l}\text { Tested concentration of the } \\
\text { compounds } \\
(\mu \mathrm{g} / \mathrm{mL})\end{array}$}} & \multicolumn{6}{|c|}{ Strains and diameter of inhibition zone (mm) } \\
\hline & & \multirow{2}{*}{$\begin{array}{c}\begin{array}{c}\text { S. aureus } \\
\text { ATCC } 25923\end{array} \\
20 \pm 0.3\end{array}$} & \multirow{2}{*}{$\begin{array}{c}\text { S. lutea } \\
\text { ATCC } 9341 \\
21 \pm 0.4\end{array}$} & \multirow{2}{*}{$\begin{array}{c}\text { C. albicans } \\
\text { ATCC } 1031 \\
28 \pm 0.5\end{array}$} & \multirow{2}{*}{$\begin{array}{c}\text { S. aureus } 5 \\
16 \pm 0.4\end{array}$} & \multirow{2}{*}{$\begin{array}{c}\text { S. aureus } 7 \\
18 \pm 0.1\end{array}$} & \multirow{2}{*}{$\begin{array}{l}\text { C. glabrata } \\
29 \pm 0,3\end{array}$} \\
\hline \multirow{3}{*}{$\mathrm{BSB}-2 \mathrm{Br}$} & 500 & & & & & & \\
\hline & 50 & $16 \pm 0.4$ & $19 \pm 0.6$ & $16 \pm 0.3$ & $16 \pm 0.7$ & $17 \pm 0.2$ & $28 \pm 0,6$ \\
\hline & 10 & $14 \pm 0.21$ & $18 \pm 0.3$ & $20 \pm 0.5$ & $15 \pm 0.2$ & $16 \pm 0.2$ & $27 \pm 0,5$ \\
\hline \multirow{3}{*}{ BSB-2I } & 500 & $20 \pm 0.3$ & $17 \pm 0.2$ & $28 \pm 0.3$ & $12 \pm 0.2$ & $14 \pm 0.3$ & $26 \pm 0,5$ \\
\hline & 50 & $18 \pm 0.2$ & $15 \pm 0.2$ & $25 \pm 0.3$ & $14 \pm 0.7$ & $13 \pm 0.2$ & $23 \pm 0,4$ \\
\hline & 10 & $15 \pm 0.3$ & $13 \pm 0.1$ & $18 \pm 0.2$ & $12 \pm 0.2$ & $12 \pm 0.5$ & $18 \pm 0,4$ \\
\hline \multirow{3}{*}{$\mathrm{BSB}-\mathrm{Cl}$} & 500 & $18 \pm 0.3$ & $20 \pm 0.3$ & $30 \pm 0.5$ & $15 \pm 0.3$ & 0 & $16 \pm 0,5$ \\
\hline & 50 & $10 \pm 0.2$ & $17 \pm 0.5$ & $23 \pm 0.7$ & $13 \pm 0.5$ & 0 & $13 \pm 0,4$ \\
\hline & 10 & $7 \pm 0.1$ & $12 \pm 0.2$ & $16 \pm 0.4$ & $12 \pm 0.2$ & 0 & $10 \pm 0,2$ \\
\hline \multirow{3}{*}{ BSB-2Cl } & 500 & $23 \pm 0.3$ & $21 \pm 0.3$ & $28 \pm 0.7$ & $16 \pm 0.3$ & $14 \pm 0.5$ & $14 \pm 0,5$ \\
\hline & 50 & $18 \pm 0.4$ & $14 \pm 0.2$ & $22 \pm 0.3$ & $12 \pm 0.1$ & $9 \pm 0.3$ & $12 \pm 0,2$ \\
\hline & 10 & $14 \pm 0.3$ & $12 \pm 0.5$ & $16 \pm 0.4$ & $7 \pm 0.1$ & 0 & $9 \pm 0,3$ \\
\hline \multicolumn{2}{|c|}{$\begin{array}{c}\text { Ampicillin } \\
(10 \mu \mathrm{g})\end{array}$} & $29 \pm 0,3$ & $33 \pm 0.5$ & - & $22 \pm 0.3$ & $25 \pm 0.3$ & 0 \\
\hline \multicolumn{2}{|c|}{$\begin{array}{c}\text { Chloramphenicol } \\
(30 \mu \mathrm{g})\end{array}$} & $28 \pm 0,2$ & $32 \pm 0.3$ & - & $25 \pm 0.4$ & $24 \pm 0.2$ & - \\
\hline \multicolumn{2}{|c|}{$\begin{array}{l}\text { Nystatin } \\
(100 \mu \mathrm{q})\end{array}$} & - & - & $29 \pm 0.3$ & - & - & $28 \pm 0.5$ \\
\hline
\end{tabular}

Table 2

IN VITRO ANTIMICROBIAL ACTIVITY OF THE COMPOUNDS AGAINST GRAM-NEGATIVE ORGANISMS

\begin{tabular}{|c|c|c|c|c|c|c|c|c|c|c|}
\hline \multirow{2}{*}{\multicolumn{2}{|c|}{$\begin{array}{l}\text { Tested concentration of } \\
\text { the compounds }(\mu \mathrm{g} / \mathrm{mL})\end{array}$}} & \multicolumn{9}{|c|}{ Strains and diameter of inhibition zone (mm) } \\
\hline & & $\begin{array}{l}\text { E. coli } \\
\text { ATCC }\end{array}$ & P. aeruginosa & E. coli 366 & E. coli & E. coli 762 & K. pneumoniae & P. mirabilis & P. aeruginosa & P. aeruginosa \\
\hline \multirow{3}{*}{$\mathrm{BSB}-2 \mathrm{Br}$} & 500 & $15 \pm 0.2$ & $20 \pm 0.3$ & $14 \pm 0.2$ & $14 \pm 0.3$ & $17 \pm 0.2$ & $16 \pm 0.4$ & $18 \pm 0.5$ & $18 \pm 0.3$ & $18 \pm 0.2$ \\
\hline & 50 & $15 \pm 0.5$ & $18 \pm 0.3$ & $13 \pm 0.3$ & $12 \pm 0.5$ & $16 \pm 0.4$ & $15 \pm 0.2$ & $17 \pm 0.3$ & $17 \pm 0.4$ & $17 \pm 0.5$ \\
\hline & 10 & $14 \pm 0.4$ & $17 \pm 0.2$ & $12 \pm 0.5$ & 0 & $15 \pm 0.6$ & $13 \pm 0.1$ & $16 \pm 0.5$ & $16 \pm 0.2$ & $16 \pm 0.3$ \\
\hline
\end{tabular}




\begin{tabular}{|c|c|c|c|c|c|c|c|c|c|c|}
\hline \multirow{3}{*}{ BSB-2I } & 500 & $13 \pm 0.3$ & $20 \pm 0.5$ & $11 \pm 0.4$ & 0 & $12 \pm 0.3$ & $10 \pm 0.2$ & $16 \pm 0.3$ & $10 \pm 0.3$ & $10 \pm 0.4$ \\
\hline & 50 & $15 \pm 0.6$ & $18 \pm 0.5$ & $10 \pm 0.3$ & 0 & $10 \pm 0.2$ & $9 \pm 0.2$ & $15 \pm 0.5$ & $9 \pm 0.4$ & $9 \pm 0.3$ \\
\hline & 10 & $11 \pm 0.4$ & $11 \pm 0.3$ & $8 \pm 0.2$ & 0 & 0 & 0 & $14 \pm 0.3$ & 0 & $8 \pm 0.1$ \\
\hline \multirow{3}{*}{ BSB-CI } & 500 & $14 \pm 0.3$ & $21 \pm 0.4$ & $10 \pm 3$ & $10 \pm 0.3$ & 0 & $15 \pm 0.5$ & $13 \pm 0.3$ & $13 \pm 0.2$ & $12 \pm 0.3$ \\
\hline & 50 & $10 \pm 0.2$ & $16 \pm 0.2$ & $8 \pm 2$ & 0 & 0 & 0 & $11 \pm 0.5$ & $8 \pm 0.1$ & $9 \pm 0.2$ \\
\hline & 10 & 0 & $13 \pm 0.5$ & 0 & 0 & 0 & 0 & $10 \pm 0.2$ & $10 \pm 0.2$ & $7 \pm 0.3$ \\
\hline \multirow{3}{*}{ BSB-2Cl } & 500 & $17 \pm 0.3$ & $15 \pm 0.2$ & $8 \pm 0.1$ & 0 & $9 \pm 0.2$ & $15 \pm 0.3$ & $8 \pm 0.2$ & $19 \pm 0.3$ & 0 \\
\hline & 50 & $14 \pm 0.6$ & $13 \pm 0.6$ & 0 & 0 & 0 & $11 \pm 0.4$ & 0 & $16 \pm 0.4$ & 0 \\
\hline & 10 & $11 \pm 0.5$ & $10 \pm 0.2$ & 0 & 0 & 0 & $8 \pm 0.2$ & 0 & $12 \pm 0.2$ & 0 \\
\hline \multicolumn{2}{|c|}{$\begin{array}{c}\text { Ampicillin } \\
(10 \mu g)\end{array}$} & $27 \pm 0.5$ & $25 \pm 0.2$ & 0 & 0 & 0 & 0 & 0 & 0 & 0 \\
\hline \multicolumn{2}{|c|}{$\begin{array}{c}\text { Chloramphenicol } \\
(30 \mu \mathrm{g})\end{array}$} & $26 \pm 0.4$ & $26 \pm 0.3$ & 10 & 8 & 9 & 8 & 0 & 9 & 0 \\
\hline \multicolumn{2}{|c|}{$\begin{array}{l}\text { Nystatin } \\
(100 \mu \mathrm{g})\end{array}$} & - & - & - & - & - & - & - & - & - \\
\hline
\end{tabular}

As shown in table 1, susceptibility after exposure to antimicrobial agents depended on the compound and bacterial species. With regard to the concentration, all compounds presented higher activity when at the highest concentration $500 \mu \mathrm{g} / \mathrm{mL}$.

The clinical isolates are most often less susceptible to tested antimicrobial agents. The ability to inhibit bacterial growth appeared more efficient especially with compound BSB-2Br. Susceptibility tests performed with three different concentrations of compound BSB-2Br, revealed that all were effective against clinical isolates (table 2).

A comparison of antimicrobial susceptibilities to Ampicillin $(10 \mu \mathrm{g})$ and Chloramphenicol $(30 \mu \mathrm{g})$ revealed that at $50 \mu \mathrm{g} / \mathrm{mL}$ concentrations, the activities were good but smaller than of those which were used as standards. Also, good antifungal activity was revealed for all compounds against Candida albicans ATCC 1031, but BSB-2Br proved an antifungal activity similar to that of Nystatin $(100 \mu \mathrm{g})$ against that particular strain. The level of sensitivity for $C$. glabrata of compound BSB-2Br at $50 \mu \mathrm{g} / \mathrm{mL}$ concentration was similar to that of Nystatin $(100 \mu \mathrm{g})$.

\section{Anti-inflammatory activity}

The percentage (\%) increase in the paw volume is illustrated in figure 2. The trend analysis, performed for the paw volume data measured during the sampling day, showed significant effects for the factor GROUP $\left(\mathrm{F}_{5,251}=11.754\right.$; $\mathrm{p}<0.001)$, for the factor TIME $\left(\mathrm{F}_{6,251}=64.601 ; \mathrm{p}<0.001\right)$, and for their interactions (GROUP $\times$ TIME) $\left(\mathrm{F}_{30,251}=3.161\right.$; $\mathrm{p}<0.001)$. The post-hoc Tukey test for multiple comparisons showed that the paw volume measured in the control group reflected a typical course of the trajectory, with the increase of inflammation one hour after carrageenan administration, and values close to basal measurements at 24 hours after carrageenan administration. The sub-plantar injection of carrageenan induced an increase of the paw volume, which was evident after one hour in all groups, with lower volume in the group that received Indomethacin, but without statistically significant differences between groups.

Indomethacin, the positive control, used as a standard anti-inflammatory drug, showed a typical anti-inflammatory trend at $10 \mathrm{mg} / \mathrm{kg}$, compared to the control group, with a statistically significant reduction in paw thickness at 4,6 , and 8 hours. Indomethacin reduced the edema by $85.3 \%$ at 4 hours, by $88.7 \%$ at 6 hours, and by $87.3 \%$ at 8 hours.

The effect of the bis-Schiff base BSB-2Br showed an anti-inflammatory trend compared to the control group, with a statistically significant reduction in paw thickness only at 6 hours and at 8 hours; only at 8 hours the antiinflammatory effect was statistically similar to that of Indomethacin. On the other hand, the trend of the antiinflammatory effect of the bis-Schiff base BSB-2I was similar to the bis-Schiff base BSB-2Br, with a statistically significant reduction in paw thickness at 6 hours and at 8 hours compared to the control group. Contrary to the bisSchiff base BSB-2Br, the bis-Schiff base BSB-2I reduced the edema by $56.4 \%$ at 6 hours, and by $73.7 \%$ at 8 hours, not statistically different of Indomethacin anti-inflammatory effect.

The effects of the bis-Schiff bases BSB-Cl and BSB-2Cl showed an anti-inflammatory trend compared to the control group, with a statistically significant reduction in paw thickness at 6 hours and at 8 hours, compared to the control group. Only after 8 hours, the anti-inflammatory effect of the bis-Schiff base BSB-2Cl was not statistically different to that of Indomethacin.

A series of novel bis-Schiff bases with halogen radicals were synthesized to identify anti-inflammatory agents with minimal ulcerogenic potential. 


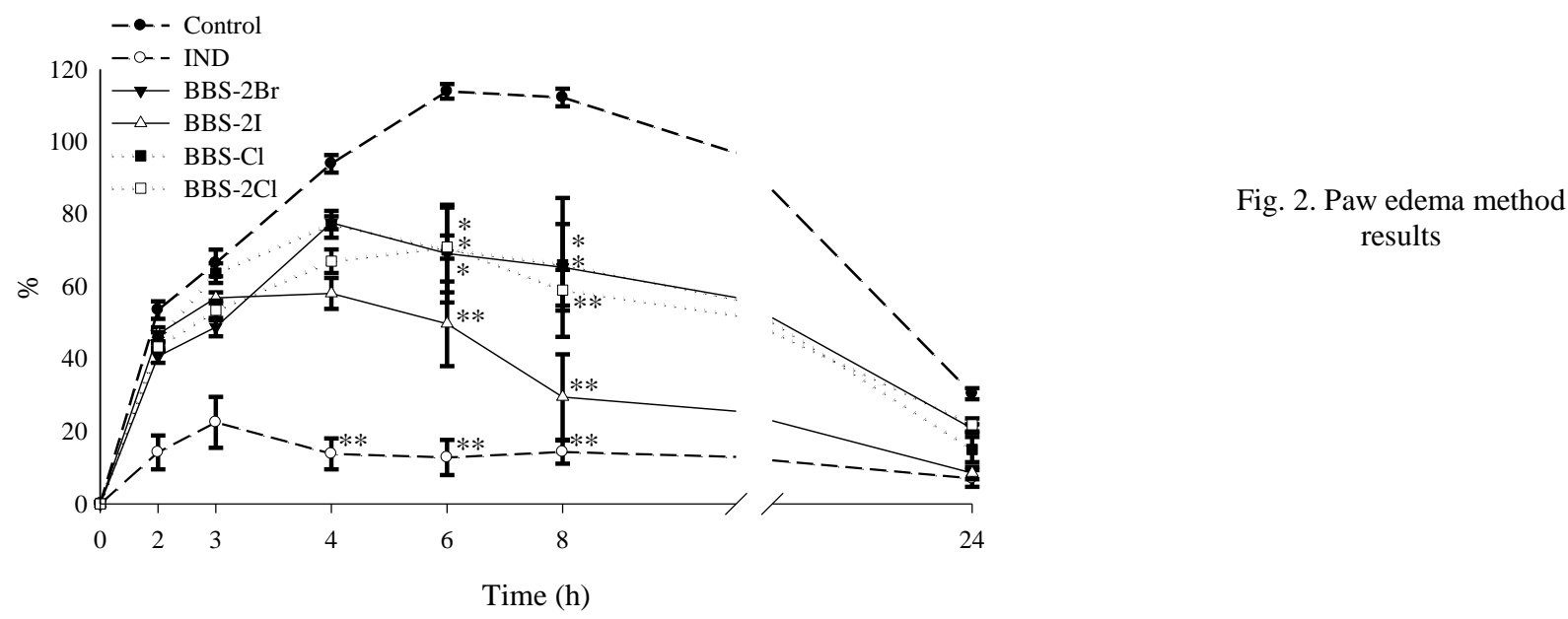

\section{Conclusions}

The results obtained in the antibacterial assay, showed that all tested compounds have a good activity against the reference strains. The results differ significantly in the case of the clinical isolates. Compound BSB-2Br that contained bromide in the ortho and para position showed the strongest action against these multi-resistant clinical isolated. The compound BSB-2Br also exhibit a very strong activity against $C$. glabrata.

The bis-Schiff base BSB-2Br reduced the edema by $45.5 \%$ at 6 hours, and by 45.3 p\% at 8 hours. Our study on the anti-inflammatory effects of new bis-Schiff bases with halogens showed that bromide attached to bis-Schiff base induced moderate anti-inflammatory effects compared Indomethacin. The bis-Schiff bases BSB-Cl and BSB-2Cl reduced the edema by $38.4 \%$, and $41.5 \%$, respectively, at 6 hours, and by $37.8 \%$, and $46.5 \%$, respectively, at 8 hours. Moreover, there were no differences between the anti-inflammatory effects when the attachment was with one or two ions of chloride. The anti-inflammatory effect of bromide attached to bis-Schiff was stronger than the antiinflammatory effect induced by chloride or iodide ions attached to bis-Schiff bases. The obtained results demonstrate the influence of grafted halides on the phenolic nucleus on the antimicrobial and anti-inflammatory activity.

\section{References}

1. ALAFEEFY, A.M., BAKHT, M.A., GANAIE, M.A., ANSARIE, M.N., EL-SAYED, N.N., AWAAD, A.S., Bioorg. Med. Chem. Lett., 25, no. 2, 2015, p. 179.

2. QIAO, X., MA, Z.Y., XIE, C.Z., XUE, F., ZHANG, Y.W., XU, J.Y., J. Inorg. Biochem., 105, no. 5, 2011, p. 728.

3. HUSSEIN, M.A., OMAR, R.H., FARGHALY, H.S., Int. J. Acad. Res., 3, no. 1, 2011, p. 454.

4. VENKATESH, P., Asian J. Pharm. Hea. Sci., 1, no. 1, 2011, p. 8.

5. MURTAZAA, S., AKHTARB, M.S., KANWALB, F., ABBASA, A., ASHIQA, S., SHAMIMA, S., J. Saudi Chem. Soc., 21, 2017, p. S359.

6. NIRMAL, R., PRAKASH, C., MEENAKSHI, K., SHANMUGAPANDIYAN, P., J. Young Pharm., 2, no. 2, 2010 , p. 162.

7. PANDEY, A., DEWANGAN, D., VERMA, S., MISHRA, A., DUBEY, R.D., Int. J. Chem. Tech. Res., 3, no. 1, 2011 , p. 178.

8. SATHE, B.S., JAYCHANDRAN, E., JAGTAP, V.A., SREENIVASA, G.M., Int. J. Pharm. Res. Dev., 3, no. 3, 2011 , p. 164.

9. KUMAR, S., DHAR, D.N., SAXENA, P.N., J. Scient. Ind. Res., 68, 2009, p. 181.

10.CHINNASAMY, R.P., SUNDARARAGAN, R., GOVINDARAJ, S., Soc. Pharm. Edu. Res., 1, no. 3, 2010, p. 342.

11. ALI, M.M., AZAD, M., JESMIN, M., AHSAN, S., RAHMAN, M.M., Asian Pac. J. Trop. Biomed., 2, no. 6, 2012 , p. 438.

12. TANTARU, G., NECHIFOR, M., APOSTU, M., VIERIU, M., PANAINTE, A.D., BIBIRE, N., Rev. Med. Chir. Soc. Med. Nat. Iasi., 119, no. 4, 2015, p. 1195 .

13.VANCOA, J., SVAJLENOVAB, O., RACANSKAC, E., MUSELIKA, J., VALENTOVAB, J., J. Trace Elem. Med. Biol., 18, no. 2, 2004, p. 155.

14. SPAC, A.F., MIFTODE, A.M., ASAFTEI, I.V., SANDU, I., Rev. Chim. (Bucharest), 69, no. 8, 2018, p. 2167.

15. MIFTODE, A.M., SPAC, A.F., DORNEANU, V., STEFANACHE, A., Rev. Chim. (Bucharest), 67, no. 4, 2016 , p. 696.

16. CRETEANU, A., OCHIUZ, L., VASILE, C., VIERIU, M., TANTARU, G., Farmacia, 65, no. 4, 2017, p. 545.

17. CRETEANU, A., OCHIUZ, L., VIERIU, M., TANTARU, G., Med. Surg. J. - Rev. Med.-Chir., 122, no. 4, 2018 , p. 840.

18. TANTARU, G., BIBIRE, N., PANAINTE, A.D., VIERIU, M., APOSTU, M., Rev. Chim. (Bucharest), 69, no. 11, 2018 , p. 3097.

19. CASCAVAL, A.L., Brevet de Inventie Ro 89577 (Cl.C07C119/06).

20. TANTARU, G., NECHIFOR, M., PROFIRE, L., Afr. J. Pharm. Pharmacol., 7, no. 20, 2013, p. 1225.

21. WINTER, C.A., RISLEY, E.A., WHESS, G.W., Proc. Soc. Biol. Med., 111, 1962, p. 544.

Manuscript received: 20.12 .2019 